\title{
"The world will always want men": Anna Julia Cooper, Womanly Black Manhood, and "Predominant Man- Influence"
}

\section{Malinda Alaine Lindquist}

In a series of essays and lectures written and delivered between 1886 and 1892 and later published in one volume, $A$ Voice from the South (1892), Anna Julia Cooper argued that what science and society had cast as a problem of race--the Negro problem - was really a problem of gender-specifically the development of Anglo-Saxon hegemonic masculinity and the complicity of white women and Black men in enshrining this problematic ideal, ideology, and practice. Through her essays and oratory, Cooper identified and contested hegemonic masculinity; recognized and delineated the possibility of multiple masculinities alongside a singular manhood ideal; emphasized a new politics of masculinity rooted in a social service, if not social justice, paradigm; and connected bodies to social action. Cooper's example offers an early theory of masculinity that places race not at the margin, but at the center of a matrix of latenineteenth century debates that frequently took for granted the connections between theories of gender and racial development and nation and civilization building. Cooper argued, and many of her contemporaries agreed, that race was not peripheral to debates about masculinity. Rather, race lay at their core and was fundamental to the development of Western masculinities. Likewise, masculinity was integral to racial debates.

In this way, Cooper both helps us to appreciate and helps to complicate the work of R. W. Connell. In his enormously influential Masculinities (1995), Connell defines hegemonic masculinity as "the configuration of gender practice which embodies the currently accepted answer to the problem of the legitimacy of patriarchy, which guarantees (or is taken to guarantee) the dominant position of men and the subordination of women." In the United States, and in much of the West, hegemonic masculinity has been as much a racial system as it is a gender system. It is as invested, if not more invested, in legitimizing a specific racial ideology and subordinating certain racial groups as it is in patriarchy and female subordination. At the turn-of-the twentieth century, Cooper saw masculinity not only as central to the problem of gender relations, patriarchy, and sexism, but also as essential to comprehending the origins of racism, imperialism, internal colonialism, and economic exploitation. She asserted that masculinity intersected with race to create a white "predominant man-influence," what today might be called an Anglo-Saxon hegemonic masculinity, which simultaneously legitimized and connected the Woman Problem to the Negro Problem and sexism to racism. Her work illuminates the intersectional-

13

(C) Left History

11.2 (Fall 2006) 
ity of race, gender, class, region, and nation and is illustrative of the interdisciplinarity of nineteenth-century intellectual thought. ${ }^{2}$ Wielding social science, theology, autobiography, literature, and history she posited theories of the individual and racial development of masculinities; outlined a Gospel-inspired manhood ideal based on Simon of Cyrene; employed masculinity to theorize the race problem and its solution; and deconstructed Anglo-Saxon hegemonic masculinity. The only orthodoxy she would have claimed was to a womanist, Africana, Christian theology that espoused the equality of sex and race based upon the New Testament Gospels.

Cooper's work also has particular meaning in the historical moment in which it was written. The closing decades of the nineteenth century and the opening decades of the twentieth were, as numerous scholars have argued, particularly difficult for African Americans. Lynching, sharecropping, debt peonage, and codified segregation choked off the emergence of political and economic equality. Scientific and social claims about Black gender deficiencies frequently justified these regimes. As Nancy Stephan, Hortense Spillers, and Maurice Wallace have argued, racial ideologies were frequently grounded on the assumption that Blacks were neither men, nor women, nor human. ${ }^{3}$ Anna Julia Cooper contested each of these misrepresentations of blackness, creating a social theory of Black womanhood, manhood, and humanity that challenged the scientific authorities, white woman's rights advocates, and the Black male elite of her day. As Elizabeth Alexander argues, Cooper "wrote out of the impulse to present a unified, serviceable vision of a future for AfricanAmericans as well as out of a simultaneous resistance to a static, monolithic view of what it was to be black, and, specifically, to be a woman." Yet, her purpose was not only to develop a new vision of blackness and womanliness, but also of manliness, weakness, and power in order to create a new social order based not on patriarchy, hierarchy, violence, and subordination, but on diversity, multiplicity, and, in Cooper's words, "universal reciprocity."

Cooper's new vision of manhood and rewriting of blackness and womanliness challenged the supremacy of white men and of a white race, contested the binary logic of male and female bodies, and revised conventional racial and gender truisms. Central to this project was the little-known biblical figure Simon of Cyrene who bore Jesus's cross for a portion of his journey towards crucifixion and resurrection. ${ }^{6}$ Cooper had a lifelong fascination with Simon of Cyrene and remembered heated discussions with the Grimkes about his religious, historical, and symbolic significance. ${ }^{7}$ Impressed with his righteous credentials, she penned a poem about Simon of Cyrene, later describing it as one of her most important publications. ${ }^{8}$ Cooper even commissioned the installation of a stained glass window depicting Simon of Cyrene as a memorial for her husband. Most importantly for this essay, she identified Simon of Cyrene as the African forefather of the Black "eternal womanly" race whose legacy chal- 
lenged the dictates of white "predominant man-influence," what I have termed Anglo-Saxon hegemonic masculinity. Time and again, Cooper, who is best known for her powerful insights into Black womanhood, meditated on, discussed, and advocated the religious, historical, and sociological significance of this male biblical figure. Essential to Cooper's social theory of gender and manhood specifically, Simon of Cyrene represented a non-racist, feminist ideal of Black and non-Black manhood. ${ }^{10} \mathrm{He}$ also symbolized the womanly nature of the African race, thus destabilizing the very notion that masculinities were housed in male bodies. Furthermore, Cooper's theory of manhood challenged nineteenth- and twentieth-century anxieties and denunciations about the feminization of African Americans, in general, and Black men, in particular; not by contesting the womanly nature of blackness, but rather by redefining womanliness as an essential element of true manhood in a modern civilization. Cooper's writings evince the intimate interconnections between womanism, masculinity, and racial theory in turn-of-the-twentieth century African-American thought. Moreover, her social theory of masculinity and manhood helps to bridge scholarly debates about her vision of womanhood, her perspective on patriarchy, and her theory of race relations. Her work also unearths the powerful anti-racist, feminist contributions Black scholars have made to masculinity studies since the nineteenth century, revising genealogies that marginalize both race and women.

\section{A "Meaningful" Gendered Division of Race: African Americans, the "Eternal Womanly," and Simon of Cyrene}

Citing the gender deficiencies of the darker races was an explicit attack on both Black manhood and womanhood. ${ }^{11}$ Labeling them effeminate, anthropologists and ethnographers like Daniel Brinton asserted that African-American men were soft and not in possession of the masculine prowess, fortitude, and competence necessary for nation-building and self-government. As children and imbeciles, they lacked both sober maturity and worldly experience, as well as the requisite intellect and reason of men. ${ }^{12}$ As savages and apes, their backwardness and ignorance of the rules of civilized society, in conjunction with their inability to control their baser instincts and urges made them dangerous, especially to white womanhood. These socio-scientific formulations forfeited Black men and women access to jurisprudence, opening the door to the special privilege of lynch law. ${ }^{13}$

Scientists cited a host of mutually reinforcing variables to justify and explain racial inequality. Wielding these physical, mental, psychological, and sexual standards, anthropologists and ethnologists resolved that blackness was essentially feminine, backward, and weak and that whiteness was inherently masculine, progressive, and strong. ${ }^{14}$ Thus while discussions of the "science of 
masculinity" at the turn-of-the twentieth century frequently begin with psychoanalysis and the individual, social science has often made clear that masculinity is as much a descriptor of races as it is of individual men and women. ${ }^{15}$ Any science, social theory, or genealogy of masculinity studies must begin with an examination of its racial origins.

Daniel Brinton clearly used the measured femininity of the African races and the masculinity of the European races to naturalize racial inequalities. ${ }^{16}$ Anna Julia Cooper, on the other hand, used the same theory of a gendered division of race to undermine these ethnological conclusions and to radically realign their hierarchical formulations. She challenged the inherent supremacy of Anglo-Saxon hegemonic masculinity and demanded its replacement with a womanly manhood, what some scholars today might call a feminist or womanist masculinity. She reasoned that it was the masculine supremacy of whiteness and of white men that forged the bulwarks of racial segregation and oppression, fueled white imperial domination, and squelched the voices and the rights of most of the nation's citizens. At the same time, she argued national and civilizational advancement hinged on the construction and perpetuation of a new manhood ideal born of the Black womanly race.

Cooper's voice echoed a few other intellectuals and romantic racialists. Theodore Tilton, editor of New York Independence, used the theory of Black racial femininity, as Mia Bay explains in The White Image in the Black Mind, to posit the moral supremacy of African Americans. In his 1863 speech "The Negro," he appeared to uphold common racial knowledge stating, "the Negro is the feminine race of the world." However, from there he asserted their feminine nature was a sign of moral authority, not degeneracy, concluding African Americans were not more "social and affectionate," but possessed "that strange moral instinctive, insight that belongs more to women than to men."17 We may never know if Cooper was familiar with Tilton's speech or Brinton's ethnological essays; certainly she was familiar with French historian Jules Michelet's assertion that "Africa is a woman" which was cited in an essay authored by her close friend, Alexander Crummell. ${ }^{18}$ A prominent Black preacher and aspiring intellectual, Crummell also subscribed to the gendered division of race theory. However, he cited portions of Michelet's Woman in order to commend the virtuous nature of African women and evince the potential for feminine virtue and chastity among her diasporic counterparts in the United States. He borrowed the following passage from Michelet: "The Negress, of all others, is the most loving, the most generating ... because of ... the richness of her heart. She is loving among the loving, good among the good .... Africa is a woman. Her races are feminine .... In many of the Black tribes of Central Africa the women rule, and they are as intelligent as they are amiable and kind."'19 Crummell shored up this description with his own personal estimation of African womanhood based on the sixteen years he spent in Liberia and West Africa. He did not 
take Michelet's argument to its potential conclusion about the race's, or in his case, Black women's moral and intellectual leadership skills as Tilton and Cooper did, but rather focused on African women's "extraordinary sweetness, gentleness, docility, modesty, and especially those maternal solicitudes which make every African boy both gallant and defender of his mother." Michelet's equation of Africans as a feminine race was employed first to substantiate Black women's native femininity and second to insist that provisions be made to support the continued inculcation of feminine virtues. The implications for Black men were that feminine women would mother brave and courageous sons. Their feminine virtues primarily reinforced conventional masculine traits. Ideally Crummell's vision of feminine races did not produce men different from those produced by masculine races, nor did they evidence any counter hegemonic masculine potential.

Cooper was not the first to interrogate the intersectionality of race and gender, but she reworked its formulation to her race's advantage by positioning gender, both womanliness and manliness, as her primary category of racial analysis, and race as her primary category of gender analysis. Employing the social science popularized by her contemporaries, Cooper transformed its substance. The result was a positive vision of her race and a theological and scientific critique of Anglo-American society, especially Anglo-Saxon hegemonic masculinity. In A Voice from the South, Cooper, like Tilton and Crummell, challenged conventional theories about African Americans' racial and gender deficiencies. She described Africans and Blacks as "the 'eternal womanly" among the nations" who willingly "accept[ed] as her mission and ideal, loving service to mankind." ${ }^{20}$ She claimed African Americans' constitution was simultaneously Christ-like and womanly in its devotion to peace over war, justice over inequality, and service over power; it was the very antithesis of Anglo-Saxon hegemonic masculinity. ${ }^{21}$ Moreover, since the dawn of the woman's era anticipated a revival of womanhood, Cooper imagined an analogously prophetic role for African Americans, the womanly race. She maintained, "America needs the Negro for ballast if for nothing else. His tropical warmth and spontaneous emotionalism may form no unseemly counterpart to the cold and calculating AngloSaxon." 22 Even as she referred to African Americans as entering their "ruddy manhood" and used the masculine pronoun "his," her description of Black people's "warmth" and "emotionalism" evoked their womanly qualities, while the coldness of whites summoned an image of sterile masculinity. ${ }^{23}$

Cooper's gendered depictions of race did not mean that womanhood was absent among whites or manhood was absent among Blacks; rather, they were used to evoke an image of each race's overall gendered constitutions and tendencies. As Hazel Carby explains, "Cooper's categories [were] not biologically dependent concepts referring to the physical differences between males and females. ${ }^{24}$ Moreover, categorizing African Americans as womanly was not a 
surprising turn given her contemporaries' proclivity to use gender to explain race. Yet, in doing so, she bolstered women's and men's positions simultaneously because her womanly race was not like a woman in the conventional sense. Her womanly race was like a man and that man was the biblical figure Simon of Cyrene. Cooper's "eternal womanly" manhood both took for granted and refused to abide by a binary logic and contested the white, patriarchal, imperial paradigm enshrined by Anglo-Saxon hegemonic masculinity.

Harkening back to racial origins, Cooper asserted that the distinctions between Anglo Americans and African Americans were simultaneously biological, cultural, historical, theological, and based upon very different patterns of male development and masculine aspiration. Recognizing African Americans' and Anglo Americans' hereditary kinship, resulting from the sexual violations Black women endured in slavery and freedom, Cooper maintained that their blood was still racially differentiated. ${ }^{25}$ She claimed that African blood separated Blacks and whites. As Kathy Glass suggests, Cooper "Strategically argue[s] two sides of the same issue ... both reject[ing] and embrac[ing] racial essentialism depending on the context of the argument at stake. ${ }^{.26}$ Faulting the dark continent for its heathen culture, Cooper nonetheless praised "the original timber from the African forests" noting their virtue and chastity. As far as she was concerned "the black side of the stream with us is pretty pure, and has no cause to blush for its honesty and integrity." On the other hand, she was skeptical of "the infusions of white blood" coursing through African Americans' veins and believed their offerings were of a decidedly lower quality. ${ }^{27}$ Examining the premodern lineage of A frican and Anglo blood, she was little impressed with white blood's masculine credentials. ${ }^{28}$ She associated Anglo blood with "bloodthirsty" pirates, who "killed and harried, burned and caroused." Mocking the royal ancestry, the blue blood, of Anglos, she traced Africa's womanly blood back to Simon of Cyrene, whom she described as the "very tame and unsanguinary individual" who aided Christ during his greatest hour of need. She continued:

a long time ago when blue blood was a distilling in the stirring fiery world outside, [Blacks] had no more heroic and daring a thing to do than help a pale sorrow-marked man as he was toiling up a certain hill at Jerusalem bearing his own cross whereon he was soon to be ignominiously nailed. This Cyrenian fellow was used to bearing burdens and he didn't mind giving a lift over a hard place now and then, with no idea of doing anything grand or memorable .... And then, too, by a rather strange coincidence this unwarlike and insignificant kinsman of ours had his home in a country (the fatherland of all the family) which had offered kindly shelter to that same mysterious Stranger when, a babe and persecuted by bloody power and heartless jealousy, He had to flee the land of his birth. 
For white hegemonic masculinity "true greatness may consist in an adamantive determination never to serve" but Cooper found "little some jarring and variance between such notions and His ideals." ${ }^{29}$ The Black womanly race, heir to Christian manhood, reveled in service and was differently gendered but decidedly manlier than the Anglo-American stock. Simon's gender duality, that is, his ability to embody and express the best qualities of manliness and womanliness - strength and care, reason and morality — made him an iconic and counter hegemonic figure.

While Christ represented manhood at its best and in its most supreme form, Cooper's Simon was the Black Adam who erased the Curse of Ham and stood by Jesus when no one else would. While the Book of Matthew identified him briefly as the "man they compelled to carry His cross," Cooper transformed him into a willing manly servant of Christ. She explained, "St. Simon was not pictured in my mind as a slave, dumb driven, as an accidental beast of burden happening at the moment to be caught in the denouement of the greatest Drama of the Universe." Rather, in Cooper's re-writing, Simon was "one elect thruout the Ages to play his part in that Drama when Asia betrayed and Europe crucifiedAfrica, predestined to come forward humbly and gladly to give Service, the peculiar contribution of 'Ethiopia's blameless Race."' 30 While feminist theologists frequently claimed that no woman betrayed Christ, Cooper made the point that by the same token neither Simon nor Africa betrayed Christ. ${ }^{31}$ Cooper's Simon of Cyrene not only gave birth to the womanly race, he also embodied Black manhood's finest qualities.

Subscribing then to the gendered division of race and theories of racial difference, Cooper proudly endorsed the notion that African Americans were "weaker," by imperial standards, than their Anglo-Saxon brethren. But her argumentation made clear that weakness was no longer a clear sign of inferiority. Writing against the grain, she turned the issue of weakness on its head, postulating that a better standard for judging races and men existed. She suggested that the strength to dominate and the power to overwhelm were neither the best nor the only measures of manhood. Mainstream ethnographers like Daniel Brinton, for example, heralded "the warrior, the hero ... the one who wins the hearts of women by his fame, and the devotion of men by his prowess." Moreover, he maintained that "waging war was the basis of all society ... the highest form of judicial action .... [and] the greatest of all ... privileges." 32 Equally, Alexander Crummell argued that civilization "fastened itself to the strong and masculine." ${ }^{\prime 3}$ Cooper's theory of Black Christian manhood and the womanly race challenged this premise by redefining strength, masculinity, and womanliness. Power was not the proof of masculinity, rather it was what one did with that power, how one wielded it to help others. She stated: "[i]t may be nobler to perish red-handed ... and then fall with an exultant yell and savage grin of fiendish delight on the huge pile of bloody corpses." If the standard for 
manhood was set by conquerors and villains then forceful power and brutal carnage were likely signs of masculine development. She continued, "it depends on where you plant your standard and who wears the white plume which your eye inadvertently seeks." ${ }^{34}$ If Christ or Simon of Cyrene were the bearers of the "white plume" then submission, not to be confused with subordination, and a life dedicated to service were closer to manhood's ideal.

Cooper's, Brinton's, Crummell's, and Tilton's understandings of masculinity and femininity are of special importance because they so quickly reveal how hegemonic masculinity need not only, or even primarily, be a function of patriarchy or the practice of men. For much of the nineteenth and twentieth centuries, hegemonic masculinity was equally a function of racism and of the practice of white supremacy in the United States. But Cooper's work also reveals something else by complicating discussions of the "science of masculinity" that generally commence with theorizing the individual. The science of masculinity is as concerned with race as it is with male and female bodies and gender roles. Moreover, when Cooper did turn her attention to the individual she defied the binary logic implicit in distinctly male and female bodies. Though women were more likely to extol womanliness, she provides several examples of masculine and manly women. And, the actual model for the womanly race was the male, biblical figure Simon of Cyrene. Refusing to be bound by a binary logic regarding either sex or race, she still suggested that there were substantive differences between Blacks and whites and women and men. As Kathy Glass asserts in Courting Communities, Cooper's "turn-of-the-century analysis called for the complexities that 'both/and' formulations allow, rather than the limitations inherent in 'either/or' binaries," while her "creative politics prove[d] to be syncretic, allowing for the deployment of binaries and hybridities on the one hand, and universalisms and essentialisms on the other." ${ }^{35}$ Finally, Cooper's theory of the gendered division of race was a starting point for a complicated theory of masculine development that was both racial and individual.

\section{Black Masculinities, Feminism/Womanism, and Cooper's Voice}

Cooper responded to the social science and racial etiquette of the late-nineteenth century by redefining the social, political, and scientific meaning and consequences of Black womanliness. She identified Simon of Cyrene as the forefather of the "eternal womanly" race, and she established a feminist, antiracist alternative to Anglo-Saxon hegemonic masculinity. Like Cooper, many of the most respected Black men of the nineteenth century were equally committed to contesting derogatory representations of blackness, and Black men, in particular. From one-time pro-emigrationist turned Civil War military recruiter and proud Freemason Martin Delany, to the former slave, abolitionist, and radical suffrage man Frederick Douglass and industrial education propo- 
nent Booker T. Washington, to the advocates of Black Christian imperialism in Africa, Black men were actively engaged in redeeming and redefining their manhood ${ }^{36}$ While many of their theories and practices challenged Black men's exclusion from Victorian, self-made, and imperial manhood, few so thoroughly redefined manhood, so purposefully argued that womanliness was essential to its redemption, and so vehemently rejected the racism, sexism, imperialism, and elitism inherent in Anglo-Saxon hegemonic masculinity. Of those men, like Delany and Douglass, who advocated and "lived into" a manhood that condemned women's subordination and advocated making more of the rights and privileges of manhood available to women, few similarly explored how the rights and responsibilities of womanliness might equally expand the possibilities of manhood. The clearest exception to this and the Black male icon that may have served alongside Simon of Cyrene "as a new mode of Black masculinity, and as an alternative to normative modes of masculinity" was Zora Neale Hurston's mythical, Black folkloric slave figure "High John De Conquer." Like Hurston's twentieth-century "High John de Conquer," Cooper's nineteenth-century Simon of Cyrene belongs to small group of images deployed by womanist scholars, who intervened into theories of race, gender, and nation and, who have been contributing to masculinity studies for over a century. ${ }^{37}$ Cooper's vision of Black manhood clearly lay alongside a host of other ideals, practices, and strategies. Through her scholarship, however, she captured a vision of what a nineteenth-century, African, and womanly-inspired counter hegemonic vision of masculinity might look like; presented a complicated social theory of manhood and masculinity and then used both to interrogate race relations, sexism, imperialism, and internal colonialism.

Important clues about her theory of manhood can be gleaned from her conceptualization of "the colored woman's office" and her own self-definition as expressed through her oratory and essays. Cooper's key intervention is to expand the gendered parameters of womanliness by wedding it to certain manly attributes, and also to expand the gendered parameters of manliness by wedding it to certain womanly attributes. For example, while Cooper emphasized women's domestic responsibilities and spoke of an ahistorical core feminine influence that was loving, merciful, and self-sacrificing, she simultaneously encouraged women's "self-development" and access to higher education, asserted their equality with men, and called for their broad entrance and incorporation into society. ${ }^{38}$ Moreover, the very format of her essays and oratory upset the racial and gender logic of the era. ${ }^{39}$ Through what Todd Vogel and Elizabeth Alexander suggest to be a "mannish" style of argumentation, Cooper embodied an expanded definition of womanhood, what might be called a manly womanhood. ${ }^{40}$ Alexander hints at Cooper's gender dualities when she describes her work as "displac[ing] the sign of 'intelligentsia' (white male) and replac[ing] it with something unique and newly named: an African-American 
intelligentsia, male and female, in the form of Cooper herself." ${ }^{41}$ Her depiction of Cooper's gender duality, that is, as something "unique ... male and female ... in the form of Cooper herself," reminds us of Simon of Cyrene, and of Cooper's general insistence that the nation foster the development of more manly women and womanly men. This is clearest, when Cooper wrote:

While we not infrequently see women who reason, we say, with the coolness and precision of a man, and men as considerate of helplessness as a woman, still there is a general consensus of mankind that one trait is essentially masculine and the other is peculiarly feminine. That both are needed to be worked into the training of children, in order that our boys may supplement their virility by tenderness and sensibility, and our girls may round out their gentleness by strength and self-reliance. ${ }^{42}$

Cooper's intellectual posture both foreshadows and goes hand in hand with her call for the development of a womanly manhood and her critique of AngloSaxon hegemonic masculinity.

Much as scholars have analyzed the content of Cooper's womanhood, there is continued debate regarding her attachment to patriarchy, on the one hand, and her criticisms of the Black male elite, on the other. While Kevin Gaines insists, and Elizabeth West concedes, that Cooper critiques Black male patriarchs, West still concludes that Cooper "ultimately submits to a male-dominant rhetoric that binds woman to a subordinate relationship with man." Un Unlike West, Martha Cutter sees Cooper marshalling Black women's voices "to override and overturn patriarchal discourse" thus creating room for other marginalized voices to unite on a free and equal basis. ${ }^{44}$ A central question posed by much Cooper scholarship is how has she been simultaneously taken up as dismantling and bowing to patriarchal authority and logic? Karen Baker-Fletcher is little disturbed by Cooper's apparent contradiction, explaining it away as common to nineteenth-century feminist argumentation. ${ }^{45}$ Still, even more convincing is Kathy Glass's assertion that "Cooper both deploys and dismisses conventional gender roles ... reinforc[ing] the masculine-feminine binary, and yet [as] she upsets it, encouraging men to both inhabit and transcend traditional gender identities, in order to establish a new kind of relationship with women." 46 Taking Glass's argument one step further, I contend that Cooper advocated not only a new relationship with women, but a new kind of manhood, and a new gender system in general.

A resolution to these conundrums can be gleaned through an analysis of Cooper's social theory of masculinity and manhood. Throughout $A$ Voice from the South and in "The Ethics of the Negro Question" (1902) and "Equality of Races and the Democratic Movement" (1925), Cooper disputed the logic and power of Anglo-Saxon hegemonic masculinity, what bell hooks, Johnnetta 
Betsch Cole, and Beverly Guy-Sheftall term "patriarchal masculinity" and Martha Cutter dubs the "Law of the Father." At the same time, Cooper recognized the value of manhood and its relationship to womanhood, racial progress, and civilizational development. Just as Cooper questioned the precepts of femininity in an effort to create room, esteem, and awe for a new brand of manly womanhood, Cooper overturns the logic of white, imperial, patriarchal masculinity and replaces it with a revolutionary brand of womanly manhood. Her ability to dwell both in and beyond racialized gender essentialisms is fundamental to unraveling the riddle of Cooper's politics and social theory. Simon of Cyrene was also a key part of this puzzle because his gender duality exemplified the womanly manhood that Cooper's envisioned as replacing AngloSaxon hegemonic masculinity. So that while Cutter is right that Cooper contested the Law of the Father, West is equally accurate in her assertion that Cooper maintained a certain respect for male authority. However, it was the authority of a new Black man, father, brother, and son born of the legacy of Simon of Cyrene.

This rereading of Cooper builds on recently expanded scholarly perceptions of her work. Just as Charles Lemert has argued for the incorporation of $A$ Voice into the social theory canon of sociology and Karen Baker-Fletcher has described Cooper as a "theological anthropologist," I argue that Cooper's Voice also demands incorporation into the canon of masculinity studies as a provocative example of the racial politics of masculinity during the late-nineteenth century. ${ }^{47}$ Cooper's first set of essays- "Womanhood: A Vital Element in the Regeneration and Progress of a Race," "The Higher Education of Women," "Woman versus the Indian," and "The Status of Woman in America"- have garnered the most feminist scholarly attention, but her second set of essays"Has America a Race Problem? If so, How can it best be Solved?", "The Negro as Presented in American Literature," "What Are We Worth?", and "The Gain from a Belief"- when read through the lens of the first set evince the prominence of masculinity in Cooper's writings about womanhood, race, and race relations. Cooper understood gender as essentially relational, thus theories of manhood development and critiques of Anglo-Saxon hegemonic masculinity resonated in many of her essays. Furthermore, she suggested a causal relationship between male domination and racial ideology. The coupling of these twin discourses into an Anglo-Saxon hegemonic masculinity lay at the very heart of the text forging a connection between the two sets of essays and between the two movements she hoped would join together-the movements for woman's and racial equality-to topple Anglo-Saxon hegemonic masculinity.

\section{"The world will always want men"}

Cooper is of course best known for her discussion of women, and for the oft- 
repeated phrase "Only the BLACK WOMAN can say, "when and where I enter, in the quiet, undisputed dignity of my womanhood, without violence and without suing or special patronage, then and there the whole Negro race enters with $m e$."' 48 However, the world Cooper imagined and the world she was speaking to was, in her mind, a deeply masculine if not troublingly hyper-masculine space. And while giving a voice to Black women was surely at the forefront of her agenda, what this Black woman's voice had to say about manhood and masculinities were of equal importance. First, because she understood that to transform one was to transform the other. Womanhood and manhood were interdependent entities with women described as the first to "form the man by directing the earliest impulse of his character" and simultaneously "as a sacred charge to be sheltered and cared for with a brother's love and sympathy." ${ }^{\prime 49}$ Her essays were proscriptive and prescriptive of masculinities, white and Black. Second, her conceptions of masculinities were inseparable from her theories of womanliness and racial development. In theorizing Black womanhood, she necessarily theorized Black manhood and white masculinities and femininities.

Cooper used social science, theology, autobiography, and literature to produce a complicated theory of manhood development and masculine overdevelopment. Manhood development was generational, dependent on the condition, education, and training of great grandmothers and mothers. ${ }^{50}$ At once distinct from and complementary to Black womanhood, Black manhood was the public emulation of the private values fostered by Black women. ${ }^{51}$ She wrote, "[i]t may be, and often is, a man who weeps over the wrongs and struggles for amelioration; but that man has imbibed those impulses from a mother rather than from a father and is simply materializing and giving back to the world in tangible form the ideal love and tenderness, devotion and care that have cherished and nourished the helpless period of his own existence." ${ }^{52}$ The overlap in women's and men's capacities, however, did not mean that the sexes were interchangeable. Black men were expected to marshal the character and integrity that Black women nurtured in them to accomplish a distinct and primarily public set of tasks.

Manhood development was not entirely shaped by nature or nurture. Cooper understood the production of manhood as a complicated process requiring a strong germ, devoted parental investment, individuality, creativity, and hard work, as well as a broader societal commitment to its development. Moreover, manhood was not limited by class, race, or station. Cooper wrote:

[a] sound manhood, a true womanhood is a fruit which the lowliest can grow. And it is a commodity of which the supply never exceeds the demand. There is no danger of the market being glutted. The world will always want men. The worth of one is infinite. To this value all other values are merely relative. Our money, our schools, our governments, our free institutions, our systems of reli- 
gion and forms of creed are all first and last to be judged by this standard: what sort of men and women do they grow? .... You propose a new theory of education; what sort of men does it turn out? Does your system make boys and girls superficial and mechanical? Is it producing of average percentages or a rounding out of manhood—a sound, thorough, and practical development-or a scramble for standing and marks?

For Cooper it took a family, it took the individual, and it took the community and state institutions to develop manhood. Education was also essential to its production. Cooper described education as "the safest and richest investment possible to man. It pays the largest dividends and gives the grandest possible product to the world--a man." ${ }^{53}$ Manhood was equally a product of institutions and democratic forms of governance. ${ }^{54}$ She posited, "our form of government ... must be brought to the bar to be tested by this standard," and continued, "[i]s it developing a self respecting freedom, a sound manliness on the part of the individual?"s5 Manhood and manliness were prized commodities, within the reach of all men and races, but difficult to grow when Anglo-Saxon hegemonic masculinity subordinated women and non-whites, deprioritized education, and built institutions that bred corruption instead of a democratic manhood. Cooper's theories of manhood and masculinities were, then, extremely complicated.

R. W. Connell suggests that masculinity is hard to get a handle on, especially since it has historically been defined in at least four ways. First, by essentialists to represent "the core of the masculine"; second, by positivist social science to speak about the facts of what men are; third, as normative, in conjunction with a masculine ideal that should be striven toward; and, fourth, as semiotic, as a symbolic opposition to femininity. While he neatly parses masculinity studies down to these four approaches, plus his own provocative theory of body-reflexive practices, the tensions embedded in Cooper's approach reflect the discordant masculinity debates Connell alludes to. ${ }^{56}$ Cooper approached masculinities from each of these perspectives and her essays are messy, but the richer for it, capturing the densely layered and complicated meanings of masculinities and manhood at the turn-of-the twentieth century. Cooper's multidisciplinary and multilayered approach to the study of masculinities, womanliness, and race may appear contradictory and quite out of place in terms of today's strict adherence to disciplinary boundaries, rigorous methodologies, and separation between the academy and theology. Yet her approach is also more indicative of the complicated nature of racialized gender debates of the turn-of-the twentieth century. In Connell's terms it would be fair to say that Cooper adopted essentialist, anti-positivist, normative, symbolic, and bodyconscious definitions of masculinities. This approach allowed her to place a Christian feminist manhood ideal into conversation with a) the multiple reali- 
ties of men's lives in the $1890 \mathrm{~s}, \mathrm{~b}$ ) a multigenerational history and cultural critique of Anglo-Saxon hegemonic masculinity, and c) the twin theories of underdeveloped manhood and overdeveloped masculinity against the backdrop debate between womanliness and femininity.

At its core, Cooper asserted that masculinity was physical, dominating, and truth-seeking by nature. She wrote, "the man is more noble in reason .... he is indefatigable in pursuit of abstract truth." ${ }^{957}$ This essential masculine nature was largely responsible for nation building, but as nations evolved they required more and more of the feminine influence - sympathy, empathy, and advocacy -if their intention was equally civilization building.

As an anti-positivist, Cooper did not believe that men could be reduced to a simple formula. In her final essay, "The Gain from a Belief," Cooper asked of the positivist, "'[w]hat is man?-A curiously fashioned clock; a locomotive, capable of sensations; a perfected brute." She was unsatisfied by all formulations that limited man's capacity or suggested his "nature and destiny ... [was] as inevitable and uncontrollable as [we]re the laws of gravitation and chemical affinity." ${ }^{" 58}$ Men could not be reduced to simple facts. Moreover, to reach their highest development men (and women) needed to "believe in the infinite possibilities of devoted self-sacrifice and in the eternal grandeur of the human idea heroically espoused." ${ }^{\prime 9}$ According to Cooper, faith was the power that propelled men and women to their highest development and belief made "heroism, devotion, and sacrifice" possible. Together faith and belief generated manhood, womanhood, and civilization.

While rejecting what she termed the skeptical spirit, Cooper was still quick to describe men as they were, and specifically how she and others encountered them in the world. White and Black men were a complicated sort. Moreover, nationality, history, and experience mattered. All white men were not the same. Cooper was quite impressed with the courteous white men she encountered abroad. ${ }^{60}$ She recognized that African Americans suffered greatly at the hands of white men, but she equally praised their white male defenders along with white men's tendency to embrace women's access to a liberal education. As for Black men, she was critical of their shortsightedness on the question of women's education and of their attempts to emulate a problematic white masculine ideal..$^{61}$

Cooper did not idealize white or Black men, but her descriptions of Black men were substantively different from those regarding white men. She often faulted Black men for their ignorance, absence, and failure to request even that which they rightfully deserved. White men, on the other hand, she charged with brutality. ${ }^{62}$ They overestimated their importance and manifested a repulsive sense of entitlement. Lower-class white men were condemned for abusing Black women and upper-class white men were castigated for their imperial pursuits. Thus, at the very moment when Black men's purported violent sexual 
tendencies were popularized, pathologized, and remedied with lynch law, Cooper made clear that white men, not Black, perpetrated the most violent acts within and beyond the nation's borders.

In her essay "The Ethics of the Negro Question," Cooper clarified her commitment not only to speaking for Black women, but also "to voice the Black man's woe." ${ }^{3}$ Here, she was also quite specific about the differences between Black and white men. Contesting the myth of the Black rapist that emerged in the wake of the Civil War, she asked, "[h]ave a race of men to whom masters not over kind were not afraid to entrust their helpless women and children ... suddenly becom [e] such monsters of lust and vindictiveness that a woman is not safe on the same highway with them?" ${ }^{64}$ She also stressed, "[t]he black man is not a saint, neither can he be reduced to an algebraic formula"; the same was true for white men. Still, she held white men accountable for the "demoniacal lawlessness" of lynching, describing lynching as "an outburst of diabolism that would shame a tribe of naked savages" and lynchers as "[h]uman creatures with the behavior of hyenas [who] contended with one another for choice bones of their victim as souvenir of the occasion." ${ }^{15}$

As the history of slavery and the reality of lynching proved, Black men as members of the womanly race were potentially different from white men. But their natures, according to Cooper, were too frequently distorted by an inculcation of white men's values. For example, in her discussion of what held Black men back from fully supporting Black women's development, she looked to politics and the tendency of Black men to emulate and be guided by AngloSaxon hegemonic masculinity. She asserted, "[a] good deal depends on where we put the emphasis in this world; and our men are not perhaps to blame if they see everything colored by the light of those agitations in the midst of which they live and move and have their being." This false light, according to Cooper, was one which "exaggerate[d] the importance of mere political advantage" and offered "fictitious valuations on those able to secure such advantage." She challenged the supremacy of a masculine ideal contingent on political stature and offered as its replacement "the thinker and the doer, the man who solves the problem by enriching his country with an invention or by a thought inestimable." The problem, as she saw it, was the need to redefine Black men's ideal and, in so doing, redefine their conception of the status of woman. In a persuasive tone, she prodded Black men, saying, "surely American politics is hardly a school for great minds." Rather, it develops "taking advantage of present emergencies" and "selfishness rather than consecrated benevolence is its passport to success." The politics of Anglo-Saxon hegemonic masculinity did not cultivate men but "manipulators" and "jugglers." She concluded, "it is conducive neither to profound statesmanship nor to the higher type of manhood." Moreover, a worldview that ranked politics and politicians as its highest ideal was one that would continue to view women as "a nonentity." Cooper ascribed 
many of men's shortcomings to the troubling norms white men created and Black men emulated. ${ }^{66}$

Notwithstanding men's many flaws, Cooper simultaneously espoused a true esteem for manhood based on her embrace of a feminist theology that looked to Christ as an exemplar of manhood. ${ }^{67}$ Christ symbolized the perfect son and the perfect man. She asserted that God's "most precious gift to the world for all time [was] His Son." She continued: "[t]he most valuable contribution that can delight a nation, the noblest gift that God or man can bestow, the proudest gem that monarch can covet, the crowning point of evolution's progress is the replica of that gift in the fullness of the measure of the stature of Christ Jesus, the Perfect Man." ${ }^{18}$ Like the nineteenth-century Christian feminists Carolyn Haynes has studied, Cooper was "radically obedient" in her observance of the Bible, while subverting standard Protestant interpretations of conventional gender roles. ${ }^{6}$ Cooper credited Christ with advancing woman's cause and opening the door to "reverence for woman as woman regardless of rank, wealth, or culture." Christ sanctioned the equality of the sexes and "refused to countenance the shameless and equally guilty monsters who were gloating over her fall." Furthermore, Cooper attested that He left explicit instructions for men regarding their treatment of women. She advised her readers, $\mathrm{He}$ "has given to men a rule and guide for the estimation of women as an equal, as a helper, as a friend, and as a sacred charge." ${ }^{.70}$ Cooper christened Christ woman's first advocate, defender, and protector. A fundamental measure of his manhood was his respect for womanhood, including his respect for women's equality. She appealed to Black men, asking them to aspire to a higher ideal, saying: "[w]e need men who can let their interest and gallantry extend outside the circle of their aesthetic appreciation; men who can be a father, a brother, a friend to every weak, struggling unshielded girl."."1

Assenting to certain scientific theories, she refuted cultural relativism and countered that there was "but the one ideal of perfect manhood and womanhood, the one universal longing for development and growth ... in all the heartthrobs of humanity in whatever race and clime" which originated from Christ and His Gospel. ${ }^{72}$ In spite of her claim of a universal standard of manhood, Cooper was cognizant of a multiplicity of masculinities and was specifically concerned with the negative ramifications of Anglo-Saxon hegemonic masculinity. Based on her Christian manhood ideal, Anglo-Saxon hegemonic masculinity was fraudulent and essentially unchristian. Moreover, Cooper eschewed "demagogues" and "politicians" and all forms of personal ambition and gain. She expressed the greatest esteem for men of "intellect, heart, and race devotion, men to whom the elevation of their people means more than personal ambition and sordid gain." 73

One might argue that these descriptors replicated what she saw as the essential traits of womanliness. This would not be completely wrong because 
as much as Cooper essentialized the feminine and the masculine as separate, complementary, and distinct, she simultaneously conceived of both as "intimately interwoven," "intricately interpenetrated," and best expressed when fully embodied and intermeshed in men, women, nations, and races. ${ }^{74}$ In just the way Vivian May argues that "Cooper advocate[d] shifting philosophical and political practices toward holism, thereby refusing to separate mind from body, reason from emotion, and theory from action," Cooper refused to separate manliness from womanliness. ${ }^{75}$ Thus a notion of gender duality lay alongside a seemingly essentializing gender ideology. Womanhood and manhood, as Cooper described them, transversed both the public and private spheres. Not uncommon to the period, Cooper saw manhood as more public than womanhood, however, manhood was also distinctly private in its formulation since it was a product of motherly training and measured by its commitment to family, women, and race progress. Similarly, even as men's duties were conventionally likened to those of a soldier in war, Cooper simultaneously referred to women as "young recruit[s]" working along side "the masculine battered ... toil-worn ... grim veteran." "

Cooper spoke from this multilayered framework when critiquing AngloSaxon hegemonic masculinity. While she was highly critical of white women, ascribing a certain level of blame to them for the poor training of their sons and husbands, she clearly imagined that they along with African-American men and women and other subordinated groups needed to come together to overthrow Anglo-Saxon hegemonic masculinity. And here the differentiation between men and the masculine is most clear. Cooper explained the war for the nation's future was not between women and men. Rather it was between everyone and an Anglo-Saxon hegemonic masculinity that championed bullies and cowards through its blatant worship of power and strength to the detriment of both the nation and a democratic philosophy of "universal reciprocity." "?

\section{The "civilized world has been like a child brought up by his father"}

Given its complex origin, manly development was a serious problem, but even more troubling to Cooper was masculine overdevelopment. Cooper diagnosed white men with an overdeveloped masculinity and the nation as struggling with a "predominant man-influence" that produced racist and sexist ideologies through a pattern of domination, subordination, and complicity. While "predominant man-influence" generated the perception that African Americans were the nation's sickly patient, she suggested that white men were the real patients and it was their malady which required care. Here Cooper connected the bodies and individual performance of masculinities to the creation of a racially-stratified social world. More specifically, she connected the history of white men to a theory of Anglo-Saxon hegemonic masculinity and proposed an 
equally gendered resolution to the problem she laid out. For Cooper, these problems were as much about race as they were about masculinity.

In $A$ Voice from the South, Cooper essentially drafted a history of the rise and forecasted the impending fall of Anglo-Saxon hegemonic masculinity, what Martha Cutter refers to as Cooper's move from the "Law of the Father" to the "Law of the Feminine." 78 Blending history and social theory, Cooper asserted that for the first fourteen centuries of civilization men had dominated nearly all aspects of society. She predicted, however, that the growth of resplendent womanhood would join with manhood and inaugurate a new era in American civilization. With womanhood unbound and meeting manhood on an equal footing, the country, she wrote, that "had to limp along with the wobbling gait and one-sided hesitancy of a man with one eye" would find its total sight restored. $^{79}$ As womanhood realized its potential, the feeble body of America would be made whole. According to Cooper, men had dominated society in the past not only because they were stronger and could physically subordinate women, but also because during previous centuries their skills and masculine talents were historically more relevant.

Charting the evolution of Anglo-Saxon hegemonic masculinity in the United States, she explained that "in the pioneer days" women were essentially followers of men, dependent upon them for protection. Unable to match men physically and "contend with bear and the Indian, or to take active part in clearing the wilderness and constructing the home" she could only volunteer affection and appreciation in exchange for the industrious labor rendered by her male counterparts. "In the second or wealth producing period," she contended, men and women exhibited complementary natures with each "counteracting [the] excessive tendencies" indulged in by the other. However, during this "Accumulative Period" male dominance was still normative. The problem as Cooper put it was the white "man's love of gain and his determination to subordinate national interests and Black men's rights." His "desire for quick returns and large profits" led to "unsanitary, well nigh inhuman investments" and an "atmosphere seething with moral as well as physical impurity." These were the "legitimate products" of "[ $t]$ he cold, mathematical, selfishly calculating, so-called practical and unsentimental instinct of the business man." 80 Cooper summed up the problem as follows: the "civilized world has been like a child brought up by his father" without a "great mother heart to teach it to be pitiful, to love mercy, to succor the weak and care for the lowly." lessons, slums, tenements, disease, and racial and economic exploitation proliferated; eventually Anglo-Saxon hegemonic masculinity would destroy the nation.

The ramifications of this white patriarchal problem were even more far reaching and dangerous than "greed and cruelty," since acceptance of these twin evils led to the growth and nurture of a "sneaking admiration ... for bullies and 
prize fighters." The consequence of this admiration of Anglo-Saxon hegemonic masculinity that enshrined "the robber and wild beast adjustment of the survival of the bullies" led, according to Cooper, directly to the ideology of racial inequality. Out of this patriarchal worldview grew the belief that "dominant" meant 'righteous' and carried with it a title to inherit the earth." ${ }^{182}$ Cooper continued, "the scorn of so-called weak unwarlike races and individuals, and the very comfortable assurance that it is their manifest destiny to be wiped out as vermin before this advancing civilization" were fundamental to Anglo-Saxon hegemonic masculinity. As May asserts, "Cooper argues that violent ways of thinking connect to an ability to justify the violent eradication of all those designated as "other." "83 Cooper's image of the full and seemingly diabolical threat of white "predominant man-influence" becomes even more vivid in the following passage:

The world of thought under the predominant man-influence, unmolested and unrestrained by its complementary force, would become like Daniel's fourth beast: 'dreadful and terrible, and strong exceedingly'; 'it had great iron teeth; it devoured and brake in pieces, and stamped the residue with the feet of it'; and the most independent of us find ourselves ready at times to fall down and worship this incarnation of power. ${ }^{84}$

Recognizing the seductive and overwhelming qualities of this hegemonic masculinity whose power and strength could beguile even the most independent of thinkers, she cautioned those who might succumb to its influence that "predominant man-influence" was a monster to be feared and destroyed, not worshiped.

To prove her point about its seductive powers over even "independent" and forward looking thinkers, she offered the example of the white suffragist Mary Livermore, who in recounting a tale of a fight between an unruly American boy and a hardworking Chinese man managed to side with the "incorrigible animal" of a white boy instead of the dignified and victimized working man. Livermore's comments seemingly contested Cooper's notion of womanly power and feminine influence; and even she recognized the contradictions inherent in the anecdote. However, she then explained that Livermore's contempt for the Chinese man's weakness in terms of her complicity and worship of Anglo-Saxon hegemonic masculinity. Livermore's contempt was, according to Cooper, a product of "dwelling in the Anglo-Saxon genius for power and his contempt for weakness." That is, the influence of an Anglo-Saxon hegemonic masculinity could lead even a staunch feminist's "tongue" to "parrot over the cold conceits that some man has taught her." Such was its devouring power. ${ }^{85}$ 


\section{"Revelation of the White Man": “White Man's Dread"}

Anglo-Saxon hegemonic masculinity undermined alliances between white women and racial minorities, producing racist and sexist ideology. Cooper saw this particularly at work in literature. According to Cooper, Anglo-Saxon hegemonic masculinity biased and corrupted science and fiction, crippling and distorting the thought and reasoning abilities of a generation of writers. The problem of Anglo-Saxon hegemonic masculinity, and its imposition of the idea that African Americans could be reduced to a singular "objective fact," was central to Cooper's critique of scientific and literary portrayals of African Americans. According to Cooper, such literature was valuable in so far as it was understood as a window into the white man's psyche and evidence of the distortions wrought by Anglo-Saxon hegemonic masculinity. Due to white mental degeneracy Cooper encouraged African Americans to "ourselves paint what is true." The product that she offered in $A$ Voice from the South and that she encouraged others to produce was a new "parable," a new "standard," and a more accurate measure of the "true weight of solid intrinsic manhood without being dazzled by the fact that littleness of soul is often gilded with wealth, power, and intellect. $"{ }^{986}$

Challenging their superior insight, Cooper judged white men unable to "discern diversities of individuality" and irrational when it came to discussing African Americans. Moreover, she made clear that racist literature revealed almost nothing about African Americans, but explained much about whiteness and was a "revelation of the white man," specifically of "the white man's dread." His dread was produced by unreasonable fears of Black political domination and racial impotence or "being lost as race in this virile and vigorous Black race." Cooper quelled the white man's fear on both counts, but asserted that these "dread delusions" have created in white men "fevered and jaundiced senses" requiring a "sedative" or "mental tonic.,"87 Removing "the Negro" from the microscope's lens, Cooper identified the real patients, white men, especially Southerners. Cooper asserted that many white men were hardly capable of even entering such a conversation seeing that it "stirs up a storm of feelings that men fairly grow wild and are unfit to discuss the simplest principles of life and conduct where the colored man is concerned." Ruled by "sentiment" which was "ephemeral" Cooper deemed many white men "impervious to reason." For reason and logic should have made clear that "[i]f the cultivated black man cannot endure the white man's barbarity - the cure ... would be to cultivate the white man. Civilize both, then each will know what is due from man to man." ${ }^{.9}$ Diagnosing the ailment, Cooper clarified that the cure needed first to be administered to white men.

Cooper remained hopeful, however, that women and the "eternal womanly" African- American race would "be true to her real self," attend to their heart- 
felt instinct for "sympathy and loving kindness," and form alliances with those groups trampled by Anglo-Saxon hegemonic masculinity. ${ }^{90}$ Enunciating a gendered theory of racial rights, she wrote, "[f]or woman's cause is the cause of the weak; and when all the weak shall have received their due consideration, then woman will have her 'rights,' and the Indian will have his rights, and the Negro will have his rights, and all the strong will have learned at last to deal justly, to love mercy, and to walk humbly." The battle was not between women of different races or between white women and different races, but against "the iron heel of Anglo-Saxon power and selfishness" rooted in Anglo-Saxon hegemonic masculinity. ${ }^{91}$

\section{"Predominant man-influence" versus "Universal Reciprocity"}

Cooper was confident that the nation and African Americans were on the verge of an "important transition," at the "dawn of a new day," and "in the portals of a new and untried movement on a higher plain and in grander strain than any of past has called forth"- - the woman's era. ${ }^{92}$ Cooper predicted that women's "sentiments must strike the keynote and give the dominant tone" since moral force needed to usurp the power and prominence of physical force in "this new era of American civilization." presumably recognize the rights of both, rather than only one, of the sexes; it would transform inequitable gender relations into complementary social relations." ${ }^{94}$ Cooper's fusion of social progress with the improving stature of womanhood was part of a longer tradition. In her analysis of Scottish Enlightenment thought, Rosemarie Zagarri examines multiple variations on the "four-stage theory of history in which women play a significant role." According to Zagarri, "[i]n each stage, social evolution both benefited females, by increasing their status, and depended on them, because women softened and refined men's passions." ${ }^{95}$ While Cooper's theory mimicked nineteenth-century evolutionary gender theory, she only mentioned three stages and in the final stage women and womanliness were described as dominating, not merely enlightening, forces. Moreover, in the very next breath, she connected the woman's era to the "irrepressible power" of African Americans, the womanly race, who was also "on the threshold of a new career" while the hyper-masculine races of the nineteenth century faded into the annals of history. ${ }^{96}$ Her history of the evolution and demise of Anglo-Saxon hegemonic masculinity was not conceived solely as a white patriarchal declension narrative; the end of Anglo-Saxon hegemonic masculinity opened the door for progressive peace; gender balance among races, nations, and individuals; and the development of manly womanhood and womanly manhood.

Cooper's theory of race relations in the United States was intimately connected to her gendered vision of American progress. Just as Cooper equated the 
nation's progress with the evolution of gender roles and the eventual prominence of the meek over the strong, that is, woman leading man, her theory of race relations was predicated on a similar role reversal between whites and Blacks. For Cooper the "the Negro Problem," like "the Woman Problem," was not really a problem, but an opportunity for the United States to become a better nation. She asserted that cultural uniformity led to "a monotonous dullness which means stagnation-death." Rather than worrying over the fact that the nation suffered from a "race problem" she claimed that this supposed problem was the key to national development and vitality. In fact, she argued that societies without a race problem ought to worry, since the dominance of one race led to stagnation and death. She concluded, "we would not deprecate the fact, then, that America has a Race Problem. It is guaranty of the perpetuity and progress of her institutions, and insures the breadth of her culture and the symmetry of her development. And the historians of American civilization will yet congratulate this country that she has had a Race Problem and that descendants of the black race furnished one of its largest factors." ${ }^{\text {97 }}$

Cooper's theory of race relations was inseparable from her theory of masculinity and gender imbalance in civilizational development. Just as "predominant man-influence" lead to the spread of vice, greed, and disease, "abnormally developed" races "left entirely alone" "with a preponderance of one tone at the expense of moderation and harmony" led to "stagnation-death." Moreover, following right on the heels of her final essay on womanhood, "The Status of Woman in America," "Has America a Race Problem? If so, How can it best be Solved?" drew out the intimate connections Cooper made between the "the Woman Problem," "the Negro Problem," and Anglo-Saxon hegemonic masculinity. Just as the masculine influence needed the feminine balance, the white masculine race required the Black womanly race for counterbalance. In the absence of this equilibrium, Anglo-Saxon hegemonic masculinity would continue to produce "exclusiveness" and "selfishness" and was essentially "suicidal to progress." Just as hegemonic masculinity led to terror, "one race predominance mean[t] death." ${ }^{.99}$

Cooper theorized that the race conflict could be resolved peacefully if Anglo-Saxon hegemonic masculinity was replaced by "universal reciprocity." This reciprocity was based on the sharing of power and allowed for a multiplicity of voices to be heard, including the voices of women, labour, and nonwhites. ${ }^{100}$ Moreover, "the pride, the selfishness, the prejudices, the exclusiveness, the bigotry, and intolerance, the conceit of self of race, or of family superiority" and "personal gratifications in ... distinction by birth, by blood, by sex," all the vile engines and products of Anglo-Saxon hegemonic masculinity, would be consumed in the fires of this race conflict and "leave thee nothing but thy naked manhood, solitary and unadorned." and unadorned" counter hegemonic manhood would be born of racial conflict 
and premised on a commitment to "universal reciprocity," equality, and womanliness. Kathy Glass writes, "[e]ndorsing an ethic of care and collaboration that runs counter to the capitalist philosophy urging individuals to advance at the expense of others, Cooper provides an alternative route to worldly success." $" 102$

Cooper also fundamentally redefined power, when in her final essay she wrote: "I I believe." That is power. That is the stamping attribute in every impressive personality, that is the fire to the engine and the motor force in every battery .... and that alone which makes a man a positive and not a negative quantity in the world's arithmetic." ${ }^{103}$ Manhood was not premised on the power to conquer, crush, exploit, and dominate and white men did not set a standard that excited Cooper. ${ }^{104}$ Instead Cooper identified "[t]he slave brother" as the exemplar of true belief and manhood. As she put it, "[h]e believed that somewhere under ... [the North star's] beckoning light, lay a far away country where a man's a man." She concluded: "[y]es, I believe there is existence beyond our present experience; that that existence is conscious and culturable; and that there is a noble work here and now in helping men to live into it." ${ }^{105}$ As BakerFletcher posits, "[h]er overarching goal was the universal freedom and development of the human race-male and female."106

Through her oratory, scholarship, activism, and teaching, Cooper worked to cultivate women and men so that they might "live into" a womanhood and manhood that embodied, blended, and balanced the best attributes of womanliness and manliness, defying the logic of gender supremacies. She also worked to cultivate a race that would "live into" its womanliness, in the process redefining womanhood and manhood, rather than simply aspire to assimilation and incorporation in a nation premised on white "predominant man-influence." Rewriting blackness, whiteness, womanliness, manliness, femininity, and masculinity, she developed a racial theory of gender and a gendered theory of race that countered Anglo-Saxon hegemonic masculinity with an inclusive worldview premised on "universal reciprocity," a philosophy that repudiated all forms of domination, subordination, exclusion, and exploitation.

\section{A Race Conscious Genealogy of Masculinity Studies}

This reading of Cooper illuminates some of the limitations of the contemporary field of masculinity studies in relation to the category of race and argues not only for the inclusion of Cooper's womanist Voice in the "science of masculinity," but also for the recognition of a black feminist tradition that has interrogated the race of masculinities and the masculinity of race since the nineteenth century. In the decade since the publication of R. W. Connell's extremely important book Masculinities, psychologists, sociologists, historians, and literary and gender scholars have been at the forefront of a new and exciting litera- 
ture on Black masculinities. ${ }^{107}$ Masculinities, however, sits on the fulcrum between what Maurice Wallace terms the first and second waves of masculinity studies. ${ }^{108}$ With the exception of the work of a few social scientists, Afrocentrists, and feminist scholars, most of the first wave of masculinity scholarship, especially historical works, focused on white manhood. ${ }^{109}$ Connell's Masculinities suggests the importance of race, writing "[r]ace relations may also become an integral part of the dynamic between masculinities," yet race remains external not intrinsic to his theory of Western masculinities. Moreover, many among this first generation of scholars were unable to conceive of Black masculinities as anything other than what Martin Summer's terms "negative referents" or as playing "symbolic roles for white gender construction." 110 Thus, it is not altogether surprising that Connell circumscribes his discussion of race to a theory dubbed "marginalization" and, with the exception of Robert Staples, largely ignores both the scholarship and political activism of non-whites. ${ }^{111}$ Still, Connell's work helped to begin an important conversation about the "science of masculinity."

Likewise, Cooper's work can be read as responding to the turn -of -the twentieth-century "science of masculinity." Taking part in an intellectual project similar to that of Freud, Alder, Horney, and Connell, Cooper's Voice belongs alongside these major theorists of masculinity studies. Connell's "science of masculinity" is based, first, on academic theories of masculine development produced by psychoanalysts, psychologists, sociologists, anthropologists, and historians throughout the twentieth century and, second, on the political productions of knowledge born of the women's and gay liberation movements. Although Connell describes Sigmund Freud as the first scholar to disrupt and examine the concept of masculinity, we need to also recognize that womanist scholars, such as Anna Julia Cooper, were about the same business. ${ }^{112}$ Moreover, though her work was largely written in response to Jim and Jane Crow, much of her thought anticipated the findings of the icons of masculinity studies. The tendency toward phallocentrism and heteromasculinity, as documented by Bryce Traister, however, has muted and marginalized the contributions of women, feminists, and racial minorities. ${ }^{113}$ So that while Connell can decipher in Freud's work, "the germ of a theory of the patriarchal organization of culture, transmitted between generations through the construction of masculinity," we need also examine Cooper's theory that racial supremacies, imperialism, internal colonialism, and patriarchy were transmitted through, what she termed, a "predominant man-influence."114 Likewise, just as Alfred Adler's assertion that the "pre-eminence of manliness" was "the arch evil of our culture" and his theory of "masculine protest" are incorporated into the canon, so should Cooper's theories of "predominant man-influence" and "bullyism," predating Adler's work by more than three decades. ${ }^{115}$ Furthermore, Kate Horney's psychoanalytical work on "the dread of woman" and its suggestion that "adult 
masculinity is built on over-reactions to femininity" and constructed via female subordination is heralded as a touchstone in twentieth-century masculinity debates. We, however, should also become familiar with Cooper's theory of "white man's dread," asserting that white masculinity was pathological in its concern with Black male domination and was constructed via the subordination of women and racial minorities. ${ }^{116}$

The intellectual overlaps between the foundational scholarship Connell identifies and Cooper's late-nineteenth century work are equally evident in the sociologies of masculinity. Cooper's essays anticipated both the old sociology of instrumental and expressive sex roles and the new sociology of masculinities "constructed in interactions." As discussed, her concept of "predominant maninfluence" also hints at and sheds new light on Connell's own notion of "hegemonic masculinity." Her deeply interdisciplinary and extradisciplinary approach and the social justice orientation of her essays make her voice special and require its incorporation into masculinity studies.

While Connell accurately points to the power of the women's and gay liberation movements for their challenges to the power and domination of hegemonic masculinity, we should equally turn our attention to the writings and activism of early Black feminists like Cooper, a leading member of the Black women's club movement, who explicitly theorized Black womanhood and manhood, and contested Anglo-Saxon hegemonic masculinity some three-quarters of a century earlier. ${ }^{117}$ As much as Cooper's essays can be read as scholarly articles, they were equally declarations of a Christian womanist worldview and movement. Academically and politically, Cooper is an obvious candidate for inclusion in the canons of masculinity studies.

African-American men and women have been at the forefront of the study and critique of masculinity precisely because it lay at the interstices of racial and gender ideologies. And while masculinity studies may appear a new and burgeoning field of historical and social science inquiry, Anna Julia Cooper stands as an important, if understudied, foremother of masculinity studies. Her scholarship anticipated much of the twentieth century "science of masculinity"; challenged the centrality of the individual and the body; and asserted that masculinity could only be studied and understood, in so far as the politics of womanhood and race were acknowledged and simultaneously theorized. In Anna Julia Cooper we find a Black, Christian, womanist social theorist and activist postulating a late-nineteenth-century "science of masculinity" that removes women, feminism, theology, and race from the margins and returns them to the center of masculinity studies. Her work historicizes masculinity and its study; and offers an anti-patriarchal and anti-imperialist theory of masculinity born of the womanist and civil rights politics of "universal reciprocity" during the era of Jim Crow. Recovering Anna Julia Cooper's Voice and situating her as a pioneer in masculinity studies, continues the work of removing Black masculinity 
from the margins and returning it to the center. Moreover, while bell hooks' We Real Cool: Black Men and Masculinity (2004) and Beverly Guy-Sheftall's and Johnnetta Betsch Cole's Gender Talk: The Struggle for Women's Equality in African American Communities (2003) represent strong twenty-first-century branches, and Rudolph Byrd's meditation on Zora Neale Hurston's "High John De Conquer" signifies a wide sturdy twentieth-century trunk, Anna Julia Cooper's scholarship exposes the roots of a Black feminist intellectual tradition that has been invested personally, politically, scientifically, and theologically in examining masculinity and redefining manhood since the nineteenth century. ${ }^{118}$ Expanding the current genealogy of masculinity studies, Cooper's work establishes and exemplifies Black women's theoretical innovations and illustrates how analyses of manhood and masculinity were wielded to challenge white masculine supremacy and rewrite black manhood at the turn-of-the twentieth century

The author would like to thank the two anonymous reviewers, the editors of Left History, and Nell Irvin Painter, Kevin Murphy, Tracey Deutsch, David Chang, Hiromi Mizuno, and Karen Ho for their comments on this and earlier versions of this article. The research was generously supported by a University of Minnesota Multicultural Research Award and Summer McKnight Research Award.

Notes

1. R.W. Connell, Masculinities (Berkeley: University of California Press, 1995), 77. 2. Elizabeth Alexander describes Cooper's essays as "allegory, autobiography, history, oratory, poetry, and literary criticism, with traces of other forms of address" (337). Vivian May describes Cooper's work as crossing the disciplines of literature, economics, theology, science, and political theory and "bring[ing] together areas of philosophical inquiry that are often purposefully separated (epistemology, ethics, ontology, aesthetics, political philosophy, and theology)" (74-75). She continues, "By crossing disciplinary boundaries and refusing to distinguish between mind and body, knowledge and experience, and reason and emotion, Cooper stretches preconceptions about where theories of social transformation can be located as well as who can be considered an authoritative knower" (76). See, Elizabeth Alexander, "We Must Be About Our Father's Business': Anna Julia Cooper and the In-Corporation of the Nineteenth Century African American Woman Intellectual," Signs 20 (Winter 1995): 336-356; and Vivian May, "Thinking from the Margins, Acting at the Intersections: Anna Julia Cooper's $A$ Voice from the South," Hypatia 19, no. 2 (2004): 74-91.

3. Hortense Spillers, "Who Cuts the Borders? Some Readings on "America" in Comparative American Identities: Race, Sex, and Nationality in the Modern Text, ed. Hortense Spillers (New York: Routledge, 1991); Nancy Leys Stephan, "Race and Gender: The Role of Analogy in Science," in Anatomy of Racism, ed. David Theo 
Goldberg (Minneapolis: University of Minnesota Press, 1990), 38-57; and Maurice O. Wallace, Constructing the Black Masculine: Identity and Ideality in African American Men's Literature and Culture, 1775-1995 (Durham, NC: Duke University Press, 2002). 4. Elizabeth Alexander, 341.

5. Anna Julia Cooper, $A$ Voice from the South, in The Voice of Anna Julia Cooper: including $A$ Voice from the South and other important essays, papers, and letter, eds. Charles Lemert and Esme Bhan (Lanham, MD: Rowan and Littlefield, 1998), 129 [hereafter I will refer to Lemert's and Bhan's edition as The Voice].

6. Matthew 27.32; Mark 15.20-24; Luke 23.26; and John 19:17. There are several references to Black Simons in the Bible. Simon, the Canaanite, an apostle to Christ (Matt 10:4) and Symeon Niger, or Symeon the Black (Acts 13:1), who is sometimes confused with Simon of Cyrene. See Dictionary of the Holy Bible (New York: American Tract Society, 1886), 566-567; and Philip Schaff, A Dictionary to the Bible (Philadelphia: American Sunday-School Union), 803.

7. Cooper, "The Early Years in Washington: Reminiscences of Life with the Grimkés (1951), in The Voice, 310-319. As Cooper remembered it, Reverend Grimké adopted an orthodox position on the person of Simon and was unwilling to envision him as Cooper had in her poem.

8. Anna Julia Cooper, "Simon of Cyrene," at the Howard University, MoorlandSpingarn Research Center, Box 23-4, Folder 63.

9. Cooper, $A$ Voice, 145, 74. R. W. Connell deserves credit for introducing the concept of hegemonic masculinity. In Masculinities, he references Paul Hoch's White Hero, Black Beast, noting that white masculinity was frequently constructed in relation to both white women and black men, and he describes the intersectionality between race and gender, but his actual definition of hegemonic masculinity refers only to gender and does not explicitly mention race (Connell, 75, 77). I argue that Cooper's notion of "predominant man-influence" anticipates some of Connell's concerns with hegemonic masculinity and is equally a race-conscious construct.

10. Throughout this essay, I use the terms womanist and feminist interchangeably. In its simplest sense, Karen Baker-Fletcher describes a womanist as a Black feminist or a feminist of color. In her womanist analysis of Cooper, she also suggests several practices of womanism, namely self-naming, the quest for knowledge, a determination to deconstruct negative stereotypes and replace them with positive representations, an advocacy of women's culture but not of separatism, a commitment to eradicating both racism and classism, and a focus on survival of self and community. See, Karen BakerFletcher, A Singing Something: Womanist Reflections on Anna Julia Cooper (New York: Crossroad, 1994), 154-166.

11. See Beverly Guy-Sheftall, Daughters of Sorrow: Attitudes Towards Black Women, 1880-1920 (Brooklyn, NY: Carlson, 1990) for an insightful examination of the negative appraisals of African-American women and black women's resistance.

12. Daniel G. Brinton, Races and Peoples: Lecture on the Science of Ethnography (New York: N.D.C. Hodges, 1890). For more on Brinton, see Lee D. Baker, From Savage to Negro: Anthropology and the Construction of Race, 1896 to 1954 (Berkeley: University of California Press, 1998), 26-54. See also, Stephen Jay Gould, The Mismeasure of Man (New York: W.W. Norton and Company, 1981).

13. Gail Bederman, Manliness and Civilization: A Cultural History of Gender and Race 
in the United States (Chicago: University of Chicago Press, 1995).

14. See Stephan, 38-57; and Brinton, 1-38.

15. The social sciences of that period and our own, if we remember the scholarship of Robert Ezra Park (1918) that dubbed blacks "the lady of the races" and Daniel Patrick Moynihan's The Negro Family: The Case for National Action (1965) that documented the concurrent feminization of the black family and the black male, make clear that masculinity is as much a descriptor of races as it is of individual men and women.

16. Brinton, 5-38.

17. Mia Bay, The White Image in the Black Mind: African American Ideas about White People, 1830-1925 (New York: Oxford University Press, 2000), 72-73.

18. Elizabeth West, "Cooper and Crummell: Dialogics of Race and Womanhood" in

Rhetorical Women: Roles and Representations, eds. Hildy Miller and Lillian BridwellBowles (Tuscaloosa: University of Alabama Press, 2005), 80-102.

19. Alexander Crummell, "The Black Woman of the South: Her Neglects and Her Needs," in Africa and America: Addresses and Discourse, ed. Alexander Crummell (Miami, Fla.: Mnemosyne Pub. Inc., 1969): 72-73.

20. Cooper, $A$ Voice, 145, emphasis in original.

21. Karen Baker-Fletcher suggests that Cooper identified Black women with Christ and simultaneously posited that "Christ was very much like a mother in Cooper's description." She asserts, "Cooper's feminine portrait of Christ is essential to understanding her concept of womanhood" and I would add, her concept of womanly manhood (71).

22. Cooper, $A$ Voice, 132.

23. Ibid., 61. The races in Cooper's mind were differentiated by their gender temperaments, but also generationally. African Americans were "young and full of elasticity and hopefulness of youth" compared to the "old washed out and worn out races which have already, so to speak, seen their best days." Here Cooper wielded the metaphor that likened African Americans to children and transformed it into a positive and hopeful vision of her race.

24. Hazel Carby, Reconstructing Womanhood: The Emergence of the Afro-American Woman Novelist (New York: Oxford University Press, 1987), 101.

25. Miscegenation was feared by whites, but also forcefully practiced by whites. Cooper argued that Blacks, unlike their white counterparts, were not interested in "hybridity" $(102,157)$.

26. Kathy Glass, Courting Communities: Black Female Nationalism and "SyncreNationalism in the Nineteenth Century North (New York: Routledge, 2006), 84.

27. Cooper, $A$ Voice, 165.

28. For a fascinating analysis of Cooper's perception of white blood, see Carby, Reconstructing Womanhood.

29. Cooper, A Voice, 144-145.

30. Cooper, "The Early Years in Washington," 318.

31. Evelyn Brooks Higginbotham, Righteous Discontent: The Women's Movement in the Black Baptist Church, 1880-1920 (Cambridge: Harvard University Press, 1993), 120-150.

32. Brinton, 76,78 .

33. Alexander Crummell, "The Destined Superiority of the Negro," (1877) in Destiny and Race: Selected Writings, 1840-1898, Alexander Crummell, ed. Wilson Jeremiah 
Moses (Amherst: University of Massachusetts Press, 1992), 199.

34. Cooper, $A$ Voice, 143, 144, emphasis in original.

35. Glass, $99,78$.

36. Whereas Cooper espoused a racialized genealogy of the Black womanly race born of Simon of Cyrene, Martin Delany was equally invested in examining the origins and legacies of Black manhood. In The Origins and Objects of Ancient Freemasonry: Its Introduction into the United States, and Legitimacy among Colored Men (1853) and Principia of Ethnology: The Origins of Race with an Archaeological Compendium of Ethiopian and Egyptian Civilization (1880), Delany suggested an alternate masculine "racialized genealogy" with Freemasonry born in Egypt and derived through the Black man (Wallace, 68). Just as Simon of Cyrene challenged racist Jim Crow ideologies that cast Black men as violent, lazy, and licentious, Maurice Wallace demonstrates how Black Freemasons like Delany embodied an ideal of "muscular labor, capitalist productivity, economic independence, and masculine self-sufficiency" which challenged widely circulated images of the male fugitive slave and the foolish, untrained freedman (Wallace, 64). Tolagbe Ogunleye argues that Delany was an Africana male-womanist, who supported women's access to education and professional training, and advocated women's equality in the organizations he founded. Still, Delany's own vision of Black masculinity did not differ widely from that enshrined by white Freemasonry, even as he contested its origins. Similarly, Frederick Douglass's commitment to woman's suffrage did not substantially transform his perception of manhood, even though his speeches clearly hinted that women's emancipation would be a triumph for both women and men (Douglass, 27-45). Rather, Douglass's narratives invoke the notion that manhood is gained in battle through an exhibition of physical strength and virility (Wallace, 86-95). Moreover, as Maurice Wallace explains, Booker T. Washington's "disciplinary individualism" also "envisaged ... a new class of African American men ... symbolically assimilable into the American male body politic" (Wallace, 105). Black emigrationists, like Henry Blanton Parks and Henry McNeal Turner, were equally assimilationist in their endorsement of manhood through imperialism. They contested Anglo-Saxon hegemonic masculinity by asserting that Africa was the Black man's burden. Unlike, Cooper, Washington, Douglass, and eventually Delany, emigrationists argued that Black manhood was not possible in America, but could only be attained through the development of Africa. As Michele Mitchell argues, pro-imperialists "viewed the 'Black man's burden' as a necessary step in racial redemption, as an inevitable by-product of globalized racial combat, and as a morally superior version of imperialism" (98, emphasis in original). Cooper, however, did not believe that Black manhood would be proven abroad or through imperialism of any sort. For further analysis, see, Maurice Wallace, Constructing the Black Masculine; Tolagbe Ogunleye, "Dr. Martin Robison Delany, $19^{\text {th }}$ Century Africana Womanists: Reflections on His Avant-Garde Politics Concerning Gender, Colorism, and Nation Building," Journal of Black Studies 28, no. 5 (May 1998): 628-649; Frederick Douglass, "Radical Suffrage Man," in Traps: African American Men on Gender and Sexuality, eds. Rudolph Byrd and Beverly Guy-Sheftall (Bloomington: Indiana University Press, 2001), 27-45; and Michele Mitchell, "'The Black Man's Burden': African Americans, Imperialism, and Notions of Racial Manhood 1890-1910," International Review of Social History 44 (1999), Supplement: 98: 77-99. 37. It seems hardly a coincidence and more evidence of an identifiable Black feminist 
tradition in masculinity studies that the closest parallel to Cooper's rescripting of Black masculinity can be found in what Byrd terms "the tradition of John." Rereading Zora Neale Hurston's "High John De Conquer," Byrd suggests that John is "an example of courage, hope, the regenerative powers of song, love, and the spirit, [he] is a powerful figure who symbolizes the potentialities of Black people and the potentialities of a liberated and liberating Black masculinity" (5). Like Cooper's Simon of Cyrene, John is the "embodiment of self-forgetting love," an intermediary, a man whose power is based not on force, but on "inner strength and inner resources" (5). The symmetry between their alternative modes of Black masculinity rests less on any tangible similarities between these two men and more within the anti-racist compassionate imagination of womanist scholars like Cooper and Hurston. Rudolph Byrd, "The Tradition of John: A Mode of Black Masculinity," in Traps: African American Men on Gender and Sexuality, eds. Rudolph Byrd and Beverly Guy-Sheftall (Bloomington: Indiana University Press, 2001), 1-26.

38. Cooper, $A$ Voice, 107-117, 84. Championing the cause and power of womanhood, Cooper has been both heavily critiqued for her Victorian and elitist sensibilities and praised for her ability to deploy strategic essentialisms to contest white supremacy and Victorian exclusions. For a richer analysis of these debates, see Mary Helen Washington, "Introduction," in A Voice from the South, (New York: Oxford University Press, 1988); Carby, 95-120; Claudia Tate, Domestic Allegories of Political Desire (New York: Oxford University Press, 1992); and Charles Lemert, "Anna Julia Cooper: The Colored Woman's Office," in The Voice, 1-43: 336-356.

39. Alexander, 348; and Todd Vogel, ReWriting White: Race, Class and Cultural Capital in Nineteenth Century America (New Brunswick: Rutgers University Press), 86, 87.

40. Vogel, 91. According to Vogel, "[i]n a letter to an old Oberlin professor, Cooper recalled that her commencement address evoked a faculty member's 'infinite disgust' because she 'delivered it mannishly, not pretending to read an 'essay' as a lady properly should." Thus, what Alexander and Vogel identify in Cooper was not merely a rhetorical strategy deployed in A Voice from the South, but evidence of Cooper's embrace of a manly womanhood.

41. Alexander, 338.

42. Cooper, $A$ Voice, 78. The quote continues: "[t]hat, as both are alike necessary in giving symmetry to the individual, so a nation or a race will degenerate into mere emotionalism on the one hand, or bullyism on the other, if dominated by either exclusively" and serves as a reminder of how Cooper understood gender to be embedded in individuals, races, and nations simultaneously.

43. Kevin Gaines, Uplifting the Race: Black Leadership, Politics, and Culture in the Twentieth Century (Chapel Hill: University of North Carolina Press, 1996), 128-151; West, 99.

44. Martha Cutter, Unruly Tongue: Identity and Voice in American Women's Writing, 1830-1930 (Jackson: University of Mississippi Press, 1999), 80.

45. Baker-Fletcher, 124.

46. Glass, 94.

47. Lemert, $15,33$.

48. Cooper, A Voice, 63, emphasis in original. 
49. Ibid., 59, 57.

50. Ibid., 164.

51. Ibid., 78 .

52. Ibid., 77 .

53. Ibid., 168.

54. In "Equality of Races and the Democratic Movement," an essay she wrote as a mature graduate student, Cooper asserted that democracy and democratic movements were not limited to the white races, but that democracy and the desire for equality were inspired in all humanity by God and that each race was capable of enjoying the rights and responsibilities of democratic governance. See, Cooper, "Equality of Races and the Democratic Movement," in The Voice, 291-298.

55. Cooper, $A$ Voice, 186-187, emphasis in original.

56. Connell, 67-74.

57. Cooper, $A$ Voice, 86.

58. Ibid., 189.

59. Ibid., 193, emphasis in original.

60. Ibid., 92.

61. Ibid., 85, 113; and May, 86.

62. Cooper, $A$ Voice, 61, 78, 93, 105.

63. Cooper, "The Ethics of the Negro Question," in The Voice, 209.

64. Ibid., 211. As Vivian May notes, while Cooper invoked slavery to illustrate the differences between the myth of Black men's sexual transgressions and the realities of their loyal service to whites throughout slavery and in the wake of Emancipation, Cooper did not idealize Uncle Tom (May, 77).

65. Cooper, "Ethics", 210, 212.

66. Cooper, A Voice, 113, 114.

67. Ibid., 130. Christianity was the source of Cooper's gender ideals, yet she did not recognize institutionalized religion, in this case, the Protestant Episcopal Church as a faithful purveyor of either gendered or racial equality. In fact, she critiqued the church, first, for "not calculating for the Black man's personality; not having respect ... [for] his manhood," and, second, for "not developing Negro womanhood" (66, emphasis in original). 68. Cooper, "On Education," at the Howard University, Moorland-Spingarn Research Center, Box 23-4, Folder 33.

69. Carolyn Haynes, Divine Destiny: Gender and Race in Nineteenth Century Protestantism (Jackson: University of Mississippi Press, 1998), 77-128.

70. Cooper, $A$ Voice, 56, 57.

71. Ibid., 64.

72. Ibid., 103

73. Ibid., 65 .

74. Ibid., $76,78$.

75. May, 87.

76. Cooper, $A$ Voice, 84

77. Ibid., 74, 93, 129.

78. Cutter, 67-86.

79. Cooper, $A$ Voice, 107.

80. Ibid., 110, 111. Vivian May points out that Cooper was not only condemning slav- 
ery, prison labor, and imperialism in this section, but also the inequities born of the free market (83).

81. Cooper, $A$ Voice, 73.

82. Ibid., 105,74 .

83. May, 88.

84. Cooper, $A$ Voice, 74 , emphasis in original.

85. Ibid., 75 .

86. Ibid., $160,159$.

87. Ibid., $156,157$.

88. Ibid., 162, 163.

89. Ibid., 151.

90. Ibid., 105. In her essay "Equality of the Races and the Democratic Movement" (1925), she maintained that Occidentals sustained their power through warfare, while African Americans offered the world their "Heart Talent" (297).

91. Cooper, A Voice, 105, 108.

92. Ibid., $111,112$.

93. Ibid., 117.

94. Glass, 88.

95. Rosemarie Zagarri, "Morals, Manners, and the Republican Mother," American Quarterly 44, no. 2 (June 1992): 195, 198.

96. Cooper, $A$ Voice, 117.

97. Ibid., 133.

98. Ibid., $74,122$.

99. Ibid., 126.

100. Cutter, 80 .

101. Cooper, A Voice, 129, 131.

102. Glass, 81.

103. Cooper, $A$ Voice, 195 , emphasis in original.

104. On power, Baker-Fletcher suggests that for Cooper, God is the "Singing Something in the human being .... [He] is the power of freedom and equality that moves them forward" (66, emphasis in original). Moreover, Baker-Fletcher also maintained that "[f]aith was a kind of power for Cooper" (97). For Cooper belief was central to progress (86) and development (90). Furthermore, feeling was essential to reason and morality (93). 105. Cooper, $A$ Voice, 196, emphasis in original.

106 Baker-Fletcher, 20.

107. Maggie Montesinos Sale, The Slumbering Volcano: American Slave Ship Revolts and the Production of Rebellious Masculinities (Durham NC,: Duke University Press, 1997); Darlene Clark Hine and Earnestine Jenkins, eds., A Question of Manhood: $A$ Reader in U.S. Black Men's History and Masculinity (Bloomington: Indiana University Press, 1999); Hazel Carby, Race Men (Cambridge: Cambridge University Press, 1998); Martin Summers, Manliness and Its Discontents: The Black Middle Class and the Transformation of Masculinity, 1900-1930 (Chapel Hill: University of North Carolina Press, 2004); Marlon Ross, Manning the Race: Reforming Black Men in the Era of Jim Crow (New York: New York University Press, 2004); and Steve Estes, I AM a Man: Race, Manhood and the Civil Rights Movement (Chapel Hill: University of North Carolina Press, 2005). 
108. Wallace, 1-5.

109. Jewelle Taylor-Gibbs, ed. Young, Black and Male in America: An Endangered Species (Dover, Massachusetts: Auburn House Publishing Company, 1988); Jawanza Kunjufu, Countering the Conspiracy to Destroy Black Boys Volumes 1-3. Chicago: African American Images, 1982, 1986, 1990; Richard Majors and Janet Mancini Billson, Cool Pose: The Dilemmas of Black Manhood in America (New York: Touchstone Books, 1992); Michele Wallace, Black Macho and the Myth of the Superwoman (New York: Dial Press, 1979); bell hooks, Yearning: Race, Gender, and Cultural Politics (Boston: South End Press, 1990); Anthony Rotundo, American Manhood: Transformations in Masculinity from the Revolution to the Modern Era (New York: Basic Books, 1993); and Michael Kimmel, Manhood in America: A Cultural History (New York: The Free Press, 1996).

110. Summers, 10-12; and Connell, 80-81.

111. Connell describes Staples's work as a "pioneering study of ethnic difference." Staples, however, stands not at the beginning of an African-American intellectual tradition, but rather is part of a tradition that stretches at least as far back as the nineteenth century. See, Robert Staples, Black Masculinity: The Black Male's Role in American Society (San Francisco: Black Scholar Press, 1982).

112. Connell, 8.

113. Bryce Traister, "American Viagra: The Rise of American Masculinity Studies," American Quarterly 52, no. 2 (2000): 276.

114. Connell, 10; Cooper, $A$ Voice, 74.

115. Adler quoted in Connell, 16; Cooper, $A$ Voice, 74, 78, 93, 105.

116. Connell, 11; Cooper, $A$ Voice, 156, 157.

117. Connell, 39, 42. As much as Cooper was a scholar, she was equally an activist. Cooper, along with Mary Church Terrell, and Mary Jane Patterson founded the Colored Women's League of Washington, D.C., in 1892, the same year $A$ Voice from the South was published. She was also later active in the National Association of Colored Women when the Colored Women's League became one of its first affiliates. Black clubwomen, like Cooper, advocated a racial uplift philosophy premised on self-help; were active proponents and defenders of Black womanhood and of women as racial redeemers; and offered critical appraisals of manhood and masculinity. See also, Deborah Gray White, Too Heavy a Load: Black Women in Defense of Themselves, 1894-1994 (New York: W.W. Norton, 1999).

118. We Real Cool: Black Men and Masculinity bell hook's latest collection of essays and Gender Talk: The Struggle for Women's Equality in African American Communities Johnnetta Betsch Cole's and Beverly Guy-Sheftall's examination of intraracial gender debates within the African-American community are two contemporary examples of the vital role Black feminists continue to play in theorizing masculinity. In her Preface, hooks reiterates a claim she made in an essay first published in the early $1990 \mathrm{~s}$. hooks asserts that "the primary genocidal threat, the force that endangers Black male life, is patriarchal masculinity" (xiv). She identifies Black men's embrace of Black Power as the moment when "the historical movement for racial uplift rooted in nonviolence and gender equality was ruthlessly undermined" and Black men lost touch with an "unconventional perspective on masculinity [that] had given Black males alternative grounds on which to build healthy self-esteem" (14). Writing well over a century before hooks, 
Anna Julia Cooper argued that "predominant man-influence" threatened Black women's and men's development and that Black men's embrace of white, imperial, patriarchal masculinity moved them further away from the alternate manhood ideal embodied by their Christian, African, forefather Simon of Cyrene. hooks specifically mentions Cooper's feminist legacies in We Real Cool, however, she does not directly point to how her own twenty-first-century work on masculinities echoes that of Cooper's nineteenth social theory of gender $(7,8)$. Coles and Guy-Sheftall also mention Cooper's legacy and while they do not examine her scholarship in this text, they do make the point that Cooper challenged Black male patriarchy and praised Black men who purposefully struggled for the liberation of both men and women (73-74, 95-96, 112, 130). See, bell hooks, We Real Cool: Black Men and Masculinity (New York: Routledge, 2004); and Johnnetta Bestch Cole and Beverly Guy-Sheftall, Gender Talk: The Struggle for Women's Equality in African American Communities (New York: Ballantine Books, 2003). 